JURNAL ILMU KESEHATAN BHAKTI HUSADA:

HEALTH SCIENCES JOURNAL

VOL. 12 NO. 02, DESEMBER 2021

DOI: $10.34305 / \mathrm{JIKBH} . \mathrm{V} 12 \mathrm{I} 2.336$
Ciptaan disebarluaskan di bawah

Lisensi Creative Commons Atribusi-

NonKomersial-BerbagiSerupa 4.0

Internasional.

\title{
STUDI CASE CONTROL: PEMANTAUAN PERTUMBUHAN, PEMBERIAN MAKAN DAN HUBUNGANNYA DENGAN STUNTING PADA ANAK PANTI ASUHAN DI KOTA SEMARANG
}

\author{
${ }^{1}$ Anom Dwi Prakoso, ${ }^{2}$ Akhmad Azmiardi, ${ }^{3}$ Gabriela Advitri Febriani, ${ }^{4}$ Ayu Anulus \\ ${ }^{1}$ Universitas Medika Suherman, ${ }^{2}$ Universitas Bangun Nusantara, ${ }^{3}$ AKBID Singkawang, \\ ${ }^{4}$ Universitas Islam Al-Azhar \\ anomdwiprakoso@gmail.com
}

\begin{abstract}
Abstrak
Penurunan angka stunting masih menjadi prioritas utama dalam rangka tujuan pembangunan nasional. Indonesia menjadi Negara kedua dengan angka kasus stunting tertinggi kedua di Asia Tenggara setelah Kamboja. Hasil survei Status Gizi Balita Indonesia (SSGBI) pada tahun 2019 menunjukkan bahwa 1 dari 3 anak di Indonesia terbukti mengalami stunting. Hal ini merupakan masalah serius mengingat sumber daya yang paling berharga bagi suatu negara adalah sumber daya manusia. Tujuan penelitian ini adalah menganalisis hubungan antara pemantauan pertumbuhan dan pemberian makan oleh pengasuh dengan kejadian stunting pada anak panti asuhan di Kota Semarang tahun 2019. Penelitian ini menggunakan desain kuantitatif analitik melalui pendekatan case control. Populasi dalam penelitian ini adalah seluruh anak panti asuhan di Kota Semarang. Adapun jumlah sampel dalam penelitian ini adalah 48 anak stunting sebagai kelompok kasus dan 48 anak normal sebagai kelompok kontrol dengan rentang usia 8-18 tahun dan diambil secara purposive sampling. Instrumen penelitian yang digunakan yaitu kuesioner, microtoise dan aplikasi WHO Anthro Plus. Analisis data diolah dengan spss menggunakan uji statistik chi square. Hasil penelitian menunjukkan pemantauan pertumbuhan oleh pengasuh tergolong kurang baik $(51.04 \%)$ dan pola pemberian makan tergolong kurang baik (54,17\%). Uji statistik menunjukkan bahwa kejadian stunting memiliki hubungan yang signifikan dengan pemantauan pertumbuhan $(p=0.025)$ dan pola pemberian makan $(\mathrm{p}=0.001)$. Diperlukan pemantauan kesehatan rutin dan edukasi dari petugas puskesmas kepada pengasuh tentang cara menentukan status gizi anak dan pola asuh gizi yang benar dan baik.
\end{abstract}


JURNAL ILMU KESEHATAN BHAKTI HUSADA:

HEALTH SCIENCES JOURNAL

VOL. 12 NO. 02, DESEMBER 2021

DOI: $\underline{10.34305 / J I K B H . V 12 I 2.336}$
Ciptaan disebarluaskan di bawah

Lisensi Creative Commons Atribusi-

NonKomersial-BerbagiSerupa 4.0

Internasional.

Kata kunci : Stunting, Anak panti asuhan, Pemantauan pertumbuhan, Pemberian makan

\section{Pendahuluan}

Stunting atau pendek merupakan kondisi dimana anak mengalami gangguan pertumbuhan karena akumulasi ketidakcukupan zat gizi yang berlangsung lama sehingga menyebabkan tinggi badan anak lebih pendek dibanding tinggi badan anak seusianya. Anak dapat dikategorikan stunting apabila tinggi badan atau panjang badannya kurang dari minus dua standar deviasi (-2SD) (World Health Organization, 2014). Pengurangan kasus stunting pada anak adalah prioritas pertama dari enam tujuan pembangunan dalam Target Gizi Global untuk tahun 2025. Indikator kunci dalam tujuan pembangunan berkelanjutan yang kedua yaitu tidak ada lagi kelaparan (Beal et al., 2018).

Menurut World Health Organization (WHO), kurang lebih 178 juta anak di bawah usia lima tahun di dunia pertumbuhannya terhambat karena stunting. Indonesia berada pada peringkat kedua Asia Tenggara dengan jumlah kasus stunting tertinggi. Menurut data Bank Dunia atau World Bank menyampaikan bahwa angkatan kerja di Indonesia mengalami stunting sekitar 54\% pada masa bayinya. Artinya, terdapat 54\% angkatan kerja pada saat ini merupakan penyintas stunting (Kementerian Kesehatan Republik Indonesia, 2018).

Berdasarkan hasil Pemantauan Status Gizi (PSG) tahun 2015, jumlah kasus balita stunting di Indonesia yaitu 29\%. Angka ini mengalami penurunan pada tahun 2016 menjadi 27,5\%. Namun jumlah kasus balita stunting meningkat kembali menjadi 29,6\% pada tahun 2017 (Kementerian Kesehatan Republik Indonesia, 2018). Menurut hasil Survei Status Gizi Balita Indonesia (SSGBI) menunjukkan bahwa terjadi penurunan angka stunting berada pada $27,67 \%$ pada tahun 2019 dari yang awalnya sejumlah 30,8\% pada tahun 2018 . Angka tersebut masih sangat tinggi jika dibandingkan dengan standar yang ditetapkan oleh WHO yaitu angka kasus stunting tidak boleh lebih dari 20\% (Badan Pusat Statistik, 2018).

Sedikit berbeda dengan Provinsi Jawa Tengah, trend kasus stunting di kota Semarang termasuk fluktuatif dan cenderung naik dari tahun ke tahun. Meskipun prevalensi jumlah kasus stunting masih di bawah jumlah kasus nasional, tetapi tetap memerlukan perbaikan dalam hal 
JURNAL ILMU KESEHATAN BHAKTI HUSADA:

HEALTH SCIENCES JOURNAL

VOL. 12 NO. 02, DESEMBER 2021

DOI: $\underline{10.34305 / J I K B H . V 12 I 2.336}$
Ciptaan disebarluaskan di bawah

Lisensi Creative Commons Atribusi-

NonKomersial-BerbagiSerupa 4.0

Internasional. penanganan. Prevalensi stunting di Jawa

Tengah menurut data pemantauan status gizi menunjukkan peningkatan jumlah kasus dari tahun 2014 sampai tahun 2017, yaitu $22,57 \% 22,6 \%, 23,9 \%$ dan terakhir $28,5 \%$ pada tahun 2017 (Kementerian Kesehatan Republik Indonesia, 2018).

Dampak buruk yang dapat ditimbulkan oleh stunting dalam jangka pendek adalah terganggunya perkembangan otak, kecerdasan, gangguan metabolisme dalam tubuh dan gangguan pertumbuhan fisik pada anak-anak (de Onis \& Branca, 2016; Millward, 2017). Sedangkan dampak dalam jangka panjang adalah menurunnya kemampuan kognitif dan prestasi belajar, menurunnya kekebalan tubuh serta resiko tinggi terkena Penyakit Tidak Menular (PTM) seperti obesitas, diabetes, penyakit jantung, stroke, kanker dan disabilitas pada usia lansia yang akhirnya akanan menurunkan kualitas sumber daya manusia Indonesia (Nugroho et al., 2021; Yadika et al., 2019).

Terdapat banyak faktor yang menyebabkan anak menjadi stunting. Berdasarkan penelitian Aramico et al., (2016) salah satu faktor yang mempengaruhi kejadian stunting adalah pola asuh yang buruk. Pola asuh adalah gambaran tentang sikap dan perilaku orang tua dan anak dalam berinteraksi, berkomunikasi selama mengadakan kegiatan pengasuhan (Anggraeni \& Kusuma, 2019). Pola pengasuhan anak tidak selalu hanya didapatkan dari lingkungan keluarga, tetapi bisa didapatkan dari sebuah lembaga yang menyediakan jasa pengasuhan dari tenaga professional ataupun didapatkan dari lembaga kesejahteraan anak atau panti asuhan bagi anak-anak yang tidak memiliki keluarga yang utuh atau permasalahan lainnya (Magalena, 2014).

Kesenjangan dari rasio jumlah pengasuh dibandingkan jumlah anak panti asuhan yang banyak menjadi permasalahan tersendiri karena kurangnya interaksi, komunikasi, dan perhatian secara intens sehingga permasalahan fisik dan psikologis masing-masing anak kadang luput dalam pemantauan pengasuh. Kontrol atau pemantauan secara berkala diperlukan untuk memastikan apakah anak asuh dalam kondisi sehat secara fisik, mental, sosial maupun spiritual. Dalam proses pelaksanaan kontrol dan pemantauan kesehatan perlu didukung oleh pengelola panti asuhan dalam program wajib panti asuhan (Cahyani et al., 2021).

Pola pengasuhan yang baik diharapkan agar anak dapat berkembang secara jasmani 
JURNAL ILMU KESEHATAN BHAKTI HUSADA:

HEALTH SCIENCES JOURNAL

VOL. 12 NO. 02, DESEMBER 2021

DOI: $\underline{10.34305 / \mathrm{JIKBH} . \mathrm{V} 12 \mathrm{I} 2.336}$
Ciptaan disebarluaskan di bawah

Lisensi Creative Commons Atribusi-

NonKomersial-BerbagiSerupa 4.0

Internasional. maupun rohani. Konsep pengasuhan anak meliputi pengajaran, pembujukan dan pengajaran (penghargaan dan hukuman) (Pusat Penelitian Kependudukan et al., 2009). Pola asuh diantaranya meliputi pemantauan pertumbuhan dan pemberian makan. Orang tua perlu memiliki pengetahuan tentang pemantauan pertumbuhan anak agar dapat mengetahui pertumbuhannya. Pemantauan secara rutin dan terus menerus perlu dilakukan supaya jika terdapat gangguan dalam pertumbuhan maka orang tua dapat berkonsultasi dengan petugas kesehatan yang kemudian dapat diberikan intervensi gizi secara cepat dan tepat (Sumarjono, n.d.).

Pola makan dapat memberikan gambaran asupan gizi mencakup jenis, jumlah, dan jadwal dalam pemenuhan nutrisi. Orang tua perlu memiliki pengetahuan tentang pilihan terhadap makanan apa saja yang akan dikonsumsi, sebanyak apa jumlah makanan yang dikonsumsi, siapa saja yang akan mengonsumsi, serta kapan makanan tersebut boleh atau tidak boleh untuk dikonsumsi. Semakin rendah pengetahuan ibu tentang pemberian makan pada balita, maka akan semakin rendah pula status gizi balita (Sari \& Ratnawati, 2018). Pemberian makanan pendamping ASI yang buruk berisiko membuat anak menjadi stunting (Rahmad \& Miko, 2016).

Berdasarkan hasil survei awal oleh peneliti yang dilaksanakan di panti asuhan di Kota Semarang pada 39 anak ditemukan 7 anak pendek (<-2 - >3 SD) dan anak sangat pendek( $\leq 3 \mathrm{SD})$ tidak ditemukan sama sekali. Anak yang mengalami stunting terbanyak adalah anak usia SD atau usia antara 6 tahun sampai umur 12 tahun. Berdasarkan paparan data diatas, tujuan dari penelitian ini adalah menganalisis hubungan pemantauan pertumbuhan dan pemberian makan dengan kejadian stunting pada anak panti asuhan di Kota Semarang.

\section{Metode}

Desain penelitian ini yaitu analitik observasional melalui pendekatan kuantitatif dengan menggunakan desain studi case control. Populasi penelitian ini adalah seluruh anak panti asuhan di Kota Semarang. Sedangkan sampel yang diambil adalah 48 anak stunting sebagai kelompok kasus dan 48 anak normal sebagai kelompok kontrol pada 5 panti asuhan di Kota Semarang. Teknik pengambilan sampel menggunakan purposive sampling dengan kriteria inklusi yaitu anak panti asuhan yang 
JURNAL ILMU KESEHATAN BHAKTI HUSADA:

HEALTH SCIENCES JOURNAL

VOL. 12 NO. 02, DESEMBER 2021

DOI: $\underline{10.34305 / \mathrm{JIKBH} . \mathrm{V} 12 \mathrm{I} 2.336}$

berusia sekolah dengan rentang usia 8-18 tahun. Instrumen yang digunakan dalam penelitian ini adalah kuesioner pemantauan pertumbuhan dan pemberian makan yang telah dilakukan uji validitas dan reliabilitas, alat ukur berupa microtoise untuk mengukur tinggi badan, dan aplikasi WHO Anthro Plus untuk mengetahui nilai $z$-score pada anak panti asuhan. Analisa statistik yang digunakan dalam penelitian ini yaitu analisis
Ciptaan disebarluaskan di bawah Lisensi Creative Commons Atribusi-

NonKomersial-BerbagiSerupa 4.0 Internasional.

statistik deskriptif dan analisis bivariat menggunakan uji Chi Square.

\section{Hasil dan Pembahasan}

Analisis Univariat

Deskripsi variabel penelitian secara univariat meliputi distribusi subjek penelitian berdasarkan karakteristik responden dan masing-masing variabel penelitian.

Tabel 1. Karakteristik sampel

\begin{tabular}{lcc}
\hline Karakteristik & Frekuensi (n) & Persentase (\%) \\
\hline Usia & & \\
S12 Tahun & 46 & 47.92 \\
>12 Tahun & 50 & 52.08 \\
Jenis Kelamin & & \\
Laki-laki & 53 & 55.21 \\
Perempuan & 43 & 44.79 \\
Pendidikan & & \\
SD & 49 & 51.04 \\
SMP & 27 & 28.13 \\
SMA & 20 & 20.83 \\
\hline \multicolumn{2}{l}{ Sumber: Data Primer 2019 } &
\end{tabular}

Berdasarkan Tabel 1 menunjukkan bahwa anak panti asuhan yang berumur $\leq 12$ (8-12) tahun dan menjadi subyek penelitian sebanyak 46 (47.92\%), sedangkan yang berumur $>12$ (13-18) tahun sebanyak 50 (52.08\%). Anak panti asuhan yang berjenis kelamin laki-laki sebanyak 53 anak
(55.21\%), sedangkan anak perempuan yang berjenis kelamin perempuan sebanyak 43 anak (44.79\%). Anak panti asuhan yang berpendidikan SD sebanyak 49 anak (51.04\%), berpendidikan SMP sebanyak 27 anak (28.13\%) dan berpendidikan SMA sebanyak 20 anak (20.83\%).

Tabel 2. Distribusi frekuensi variabel dalam bentuk kontinu

\begin{tabular}{llllll}
\hline Variabel & n & Mean & SD & Min & Maks \\
\hline
\end{tabular}


JURNAL ILMU KESEHATAN BHAKTI HUSADA:

HEALTH SCIENCES JOURNAL

VOL. 12 NO. 02, DESEMBER 2021

DOI: $\underline{10.34305 / \mathrm{JIKBH} . \mathrm{V} 12 \mathrm{I} 2.336}$
Ciptaan disebarluaskan di bawah

Lisensi Creative Commons Atribusi-

NonKomersial-BerbagiSerupa 4.0

Internasional.

\begin{tabular}{llllll} 
Pemantauan pertumbuhan & 96 & 6.07 & 2.30 & 1 & 11 \\
Pemberian makan & 96 & 7.31 & 2.19 & 2 & 12 \\
\hline
\end{tabular}

Sumber: Data Primer 2019

Tabel 2 menunjukkan bahwa hasil uji statistik deskriptif pada setiap variabel, diantaranya yaitu pada variabel pemantauan pertumbuhan memiliki nilai mean dan SD sebesar $6.07 \pm 2.30$ dengan nilai terendah 1 dan tertinggi 11. Variabel pemberian makan memiliki nilai mean dan SD (Standar Deviasi) sebesar $7.31 \pm 2.19$ dengan nilai terendah 2 dan tertinggi 12 .
Pengukuran variabel pemantauan pertumbuhan dan pemberian makan menunjukkan bahwa standar deviasi yang kecil $(<50 \%$ dari mean $)$ menunjukkan keberagaman yang relatif kecil, atau terdapat kesenjangan yang kecil antara skor terendah dan skor tertinggi pada data.

Tabel 3. Uji normalitas variabel pemantauan pertumbuhan dan pemberian makan

\begin{tabular}{lccccc}
\hline Variabel & Obs & Pr(Skewness) & Pr(Kurtosis) & adj chi2(2) & Prob>chi2 \\
\hline Pemantauan pertumbuhan & 96 & 0.7201 & 0.2347 & 1.58 & 0.4541 \\
Pemberian makan & 96 & 0.8606 & 0.6594 & 0.23 & 0.8935 \\
\hline
\end{tabular}

Sumber: Data Primer 2019

Tabel 3 menunjukkan bahwa hasil uji normalitas data pada variabel pemantauan pertumbuhan dan pemberian makan menggunakan skewness/ kurtosis yaitu $\mathrm{p}=0.4541 \quad$ dan $\quad 0.8935 \quad(>0.05) . \quad$ Kedua variabel memiliki distribusi data yang normal, sehingga pengelompokan variabel pemantauan pertumbuhan dan pemberian makan menggunakan dua kategori berdasarkan pada nilai mean, yaitu baik (skor $\geq$ mean), kurang baik (skor $<$ mean).

Tabel 4. Distribusi frekuensi kategori variabel pemantauan pertumbuhan dan pemberian makan

\begin{tabular}{lll}
\hline Variabel & Frekuensi (n) & Persentase (\%)
\end{tabular}


JURNAL ILMU KESEHATAN BHAKTI HUSADA:

HEALTH SCIENCES JOURNAL

VOL. 12 NO. 02, DESEMBER 2021

DOI: $10.34305 / \mathrm{JIKBH} . \mathrm{V} 12 \mathrm{I} 2.336$
Ciptaan disebarluaskan di bawah

Lisensi Creative Commons Atribusi-

NonKomersial-BerbagiSerupa 4.0

Internasional.

\begin{tabular}{lcc}
\hline Pemantauan pertumbuhan & & \\
Kurang Baik & 49 & 51.04 \\
Baik & 47 & 48.96 \\
Pemberian makan & & \\
Kurang Baik & 52 & 54.17 \\
Baik & 44 & 45.83 \\
\hline
\end{tabular}

Sumber: Data Primer 2019

Tabel 4 menunjukkan bahwa pemberian makan adalah 7.31. Diketahui pemantauan pertumbuhan dibedakan terdapat sejumlah $52(54.17 \%)$ anak panti menjadi 2 kategori yaitu baik dan kurang baik. Nilai mean atau rata-rata skor jawaban subyek penelitian pada variabel pemantauan pertumbuhan adalah 6.07. Diketahui terdapat sejumlah 49 (51.04\%) anak panti asuhan yang menganggap pemantauan pertumbuhan pengasuh "baik" dengan skor nilai $<6.07$, sedangkan 47 (48.6) anak panti asuhan lainnya menganggap pemantauan pertumbuhan pengasuh "kurang baik" dengan skor jawaban $\geq 6.07$.

Nilai mean atau rata-rata skor asuhan yang menganggap pemberian makan pengasuh "baik" dengan skor nilai $<7.31$ sedangkan 44 (45.83) anak panti asuhan lainnya menganggap pemberian makan pengasuh "kurang baik" dengan skor jawaban $\geq 7.31$.

\section{Analisis Bivariat}

Analisis secara bivariat menjelaskan tentang hubungan masing-masing variabel independen terhadap variabel dependen (stunting). Metode yang digunakan dalam analisis bivariat adalah uji Chi-Square. jawaban subyek penelitian pada variabel

Tabel 4. Hasil uji hubungan antara pemantauan pertumbuhan dan pemberian makan dengan kejadian stunting

\begin{tabular}{|c|c|c|c|c|c|c|c|c|}
\hline \multirow{3}{*}{ Variabel Independen } & \multicolumn{4}{|c|}{ Kejadian Stunting } & \multirow{2}{*}{\multicolumn{2}{|c|}{ Total }} & \multirow{3}{*}{ OR } & \multirow{3}{*}{$\mathbf{p}$} \\
\hline & \multicolumn{2}{|c|}{ Stunting } & \multicolumn{2}{|c|}{ Tidak Stunting } & & & & \\
\hline & $\mathbf{N}$ & $\%$ & $\mathbf{N}$ & $\%$ & $\mathbf{N}$ & $\%$ & & \\
\hline \multicolumn{9}{|l|}{ Pemantauan pertumbuhan } \\
\hline Kurang baik & 30 & 61.22 & 19 & 38.78 & 49 & 100 & 5.04 & 0.025 \\
\hline Baik & 18 & 38.29 & 29 & 61.71 & 47 & 100 & & \\
\hline \multicolumn{9}{|l|}{ Pemberian Makan } \\
\hline Kurang baik & 34 & 65.38 & 18 & 34.62 & 52 & 100 & 10.74 & 0.001 \\
\hline Baik & 14 & 31.81 & 30 & 68.19 & 44 & 100 & & \\
\hline
\end{tabular}

Sumber: Data Primer 2019 
JURNAL ILMU KESEHATAN BHAKTI HUSADA:

HEALTH SCIENCES JOURNAL

VOL. 12 NO. 02, DESEMBER 2021

DOI: $\underline{10.34305 / J I K B H . V 12 I 2.336}$

Tabel 4 menyajikan hasil analisis bivariat uji hubungan antara pemantauan pertumbuhan dan pemberian makan dengan stunting. Hasil analisis menunjukkan bahwa terdapat hubungan yang signifikan antara variabel pemantauan pertumbuhan dengan kejadian stunting $(\mathrm{OR}=5.04 ; \mathrm{p}=0.025)$. Diketahui bahwa pemantauan pertumbuhan oleh pengasuh yang kurang baik meningkatkan risiko 5.04 kali terhadap kejadian stunting pada anak panti asuhan di Kota Semarang.

Hasil analisis menunjukkan bahwa terdapat hubungan yang signifikan antara variabel pemberian makan dengan kejadian stunting $(\mathrm{OR}=10.74 ; \mathrm{p}=0.001)$. Diketahui bahwa pemberian makan oleh pengasuh yang kurang baik meningkatkan risiko 10.74 kali terhadap kejadian stunting pada anak panti asuhan di Kota Semarang.

Berdasarkan hasil uji Chi-Square, maka dapat disimpulkan bahwa ada hubungan antara pola pemantauan pertumbuhan dan pemberian makan dengan stunting pada anak panti asuhan di Kota Semarang karena nilai significancy atau pvalue $<0.005$. Suatu variabel bebas dapat dikatakan memiliki hubungan terhadap variabel terikat jika nilai significancy atau pvalue $\mathrm{p}$-value $<0.05$.

\section{Ciptaan disebarluaskan di bawah \\ Lisensi Creative Commons Atribusi- \\ NonKomersial-BerbagiSerupa 4.0 \\ Internasional.}

Hasil penelitian ini menunjukkan bahwa pola pemantauan perkembangan memiliki hubungan yang erat dengan kejadian stunting. Pemantauan pertumbuhan dari pengasuh yang kurang baik meningkatkan kemungkinan 5.04 kali lebih tinggi terhadap kejadian stunting pada anak panti asuhan di Kota Semarang. Berdasarkan hasil uji hubungan antara pemantauan pertumbuhan dengan pertumbuhan tinggi badan anak menggunakan uji statistik $\mathrm{Chi}$ Square diketahui p-value $=0.025$. Dari hasil p-value dapat disimpulkan bahwa ada hubungan yang signifikan antara pemantauan pertumbuhan dengan kejadian stunting pada anak di panti asuhan Kota Semarang karena karena nilai significance atau p-value $<0.05$.

Sejalan dengan penelitian sebelumnya oleh Hasan \& Kadarusman (2019) menunjukkan bahwa terdapat hubungan antara riwayat pemantauan pertumbuhan dengan kejadian stunting dengan OR 10.16 (95\%; CI:5.16-20.02), setelah dikontrol variabel akses oleh jamban yang sehat, riwayat penyakit infeksi, riwayat pemberian MP-ASI dan akses sumber air bersih. Anak balita usia 6-59 bulan yang tidak terpantau pertumbuhannya memiliki risiko terjadinya stunting 10.16 unit lebih 
JURNAL ILMU KESEHATAN BHAKTI HUSADA:

HEALTH SCIENCES JOURNAL

VOL. 12 NO. 02, DESEMBER 2021

DOI: $\underline{10.34305 / J I K B H . V 12 I 2.336}$
Ciptaan disebarluaskan di bawah

Lisensi Creative Commons Atribusi-

NonKomersial-BerbagiSerupa 4.0

Internasional. tinggi dibandingkan dengan anak balita usia 6-59 bulan yang terpantau pertumbuhannya. Pemantauan perkembangan balita sangat perlu dipantau agar jika terjadi keabnormalan akan lebih dini dapat terdeteksi, karena perkembangan pada masa balita sangat menentukan perkembangan masa selanjutnya

Hasil penelitian ini sesuai dengan penelitian yang dilakukan oleh Destiadi et al., (2015) yang menyatakan bahwa riwayat pemantauan pertumbuhan dilihat dari frekuensi kunjungan Posyandu memiliki hubungan yang signifikan dengan kejadian stunting $(\mathrm{p}=0.013)$. Hasil uji statistik regresi logistik ganda menunjukkan frekuensi kunjungan Posyandu yang memenuhi syarat menjadi variabel yang paling mempunyai pengaruh terhadap kejadian stunting. Diketahui bahwa frekuensi kunjungan Posyandu $<8$ kali memiliki risiko terjadinya stunting anak 3-5 tahun sebesar 3.003 unit lebih tinggi dibandingkan frekuensi kunjungan Posyandu $\geq 8$ kali. Orang tua yang membawa balitanya datang ke Posyandu dan melakukan pemantauan tumbuh kembang secara rutin akan terpantau status gizi dan kesehatannya, sehingga mendapatkan informasi terbaru tentang kesehatan anaknya, menentukan pola hidup sehat setiap harinya, serta dapat memberikan intervensi sesuai kaidah ilmiah jika balita mengalami gangguan tumbuh kembang.

Mendukung penelitian ini, penelitian yang dilakukan oleh Sahanggamu et al., (2017) menunjukkan bahwa paparan ibu terhadap informasi gizi dan kesehatan, disertai dengan program pemantauan pertumbuhan memiliki kontribusi terhadap prevalensi kekurangan berat badan dan stunting pada anak-anak pedesaan yang berusia di bawah lima tahun. Prevalensi stunting lebih tinggi pada anak yang tidak rutin ke Posyandu dalam 3 bulan terakhir $(p=0.018)$. Menurut Mutiara et al., (2019) praktik pemantauan pertumbuhan balita penting dilakukan oleh orang tua guna menentukan asupan makanan dan gizi yang masuk kepada sang anak dan sebagai evaluasi bagi orang tua apakah asupan makanan dan gizi yang selama ini dimasukkan sesuai atau tidak. Memantau secara langsung pertumbuhan anak dengan hanya melihat, tanpa mengukur dan mencatat tinggi badan dan berat badan tentu sulit menilai grafik pertumbuhan sang anak yang selanjutnya dapat segera diteliti apa sebabnya yang menghambat pertumbuhan 
JURNAL ILMU KESEHATAN BHAKTI HUSADA:

HEALTH SCIENCES JOURNAL

VOL. 12 NO. 02, DESEMBER 2021

DOI: $\underline{10.34305 / J I K B H . V 12 I 2.336}$

anak untuk diambil tindakan penanggulangan secepat mungkin.

Hasil penelitian ini menunjukkan bahwa pemberian makan memiliki hubungan yang erat dengan kejadian stunting. Pemberian makan dari pengasuh yang kurang baik meningkatkan kemungkinan 10.74 kali terhadap kejadian stunting pada anak panti asuhan di Kota Semarang. Berdasarkan hasil uji hubungan antara pemberian makan dengan pertumbuhan tinggi badan anak menggunakan uji statistik Chi-Square diketahui $\mathrm{p}$-value $=0.001$. Dari hasil pvalue dapat disimpulkan bahwa ada hubungan yang signifikan antara pemantauan pertumbuhan dengan kejadian stunting pada anak di panti asuhan Kota Semarang karena nilai significance atau pvalue $<0.05$.

Sejalan dengan penelitian sebelumnya oleh Aramico et al., (2016) menyatakan bahwa ada hubungan yang signifikan antara pola makan dengan stunting $(\mathrm{OR}=6.01 ; \mathrm{p}<0,001)$. Pola makan dengan kategori "kurang" memiliki risiko 6,01 kali lebih besar mengakibatkan stunting dibandingkan dengan pola makan dengan kategori "cukup", masing-masing dengan stunting $63.8 \%$ dan $22.7 \%$.

\section{Ciptaan disebarluaskan di bawah \\ Lisensi Creative Commons Atribusi- \\ NonKomersial-BerbagiSerupa 4.0 \\ Internasional.}

Hasil penelitian ini sesuai dengan penelitian yang dilakukan oleh Sari \& Ratnawati (2018) hubungan antara menunjukkan bahwa terdapat hubungan yang signifikan antara pola pemberian makan dengan status gizi balita $(p=0.01)$. Diketahui bahwa sebagian besar pola pemberian makan yang dilakukan oleh orang tua kepada balita masih tergolong kurang baik (63,3\%). Hal ini disebabkan oleh kondisi balita yang dinilai kurang mendapat asupan makanan sehari-hari serta orang tua yang cenderung memberikan makanan ringan sehingga berdampak pada anak yang menjadi tidak nafsu makan.

Mendukung penelitian ini, penelitian yang dilakukan oleh Muliyati et al., (2021) menunjukkan bahwa terdapat hubungan yang erat antara kebiasaan makan dengan kejadian stunting pada anak balita di Desa Padende Kecamatan Marawola ( $\mathrm{p}$-value = 0.014; $\mathrm{OR}=4.025)$. Anak balita yang memiliki kebiasaan makan yang kandungannya jarang sumber karbohidrat, protein, serat memiliki risiko atau peluang 4.025 kali lebih besar untuk mengalami stunting dibanding anak balita yang mempunyai kebiasaan makan yang kandungannya sering terdapat sumber karbohidrat, protein, serat. 
JURNAL ILMU KESEHATAN BHAKTI HUSADA:

HEALTH SCIENCES JOURNAL

VOL. 12 NO. 02, DESEMBER 2021

DOI: $\underline{10.34305 / \mathrm{JIKBH} . \mathrm{V} 12 \mathrm{I} 2.336}$
Ciptaan disebarluaskan di bawah

Lisensi Creative Commons Atribusi-

NonKomersial-BerbagiSerupa 4.0

Internasional.

\section{Kesimpulan dan Saran}

Dari hasil pembahasan diatas dapat disimpulkan bahwa sebagian besar anak panti asuhan menganggap pemantauan pertumbuhan dan pemberian makan oleh pengasuh tergolong kurang baik. Pemantauan pertumbuhan dan pemberian makan terbukti memiliki hubungan yang signifikan dengan kejadian stunting pada anak panti asuhan di Kota Semarang.

Diharapkan pihak Puskesmas di Kota Semarang dapat melakukan upaya penanggulangan kejadian stunting pada anak panti asuhan dengan melakukan kerja sama dengan Dinas Sosial Kota Semarang dengan mengadakan program pendataan dan pemantauan tumbuh kembang secara rutin ke panti asuhan di wilayah kerja masingmasing Puskesmas. Selain itu diharapkan petugas Puskesmas dapat memberdayakan pengasuh supaya dapat melakukan pengukuran tinggi badan dan berat anak secara rutin untuk menilai status gizi anak panti asuhan serta memperhatikan kualitas dan mengedukasi tentang cara atau susunan dalam hal penyiapan makanan yang meliputi porsi makan perhari, kandungan gizi, serta makanan tambahan yang perlu diberikan kepada anak.

\section{Daftar Pustaka}

Anggraeni, A. D., \& Kusuma, A. H. (2019). Studi Fenomenologi: Pola Asuh Orangtua pada Pembelajaran Motorik Halus Anak Attention Deficit Hyperactivity Disorder (ADHD) Usia PRA Sekolah. Jurnal Ilmu Kesehatan Bhakti Husada: Health Sciences Journal, 10(2), 106-109.

Aramico, B., Sudargo, T., \& Susilo, J. (2016). Hubungan Sosial Ekonomi, Pola Asuh, Pola Makan dengan Stunting pada Siswa Sekolah Dasar di Kecamatan Lut Tawar, Kabupaten Aceh Tengah. Jurnal Gizi Dan Dietetik Indonesia (Indonesian Journal of Nutrition and Dietetics), 1(3), 121130.

Badan Pusat Statistik. (2018). Pedoman Pelaksanaan Integrasi Susenas Maret 2019 dan Studi Status Gizi Balita Indonesia Tahun 2019. Badan Pusat Statistik.

Beal, T., Tumilowicz, A., Sutrisna, A., Izwardy, D., \& Neufeld, L. M. (2018). A Review of Child Stunting Determinants in Indonesia. Maternal \& Child Nutrition, 14(4), e12617.

Cahyani, K. O. A., Agushybana, F., \& Nugroho, R. D. (2021). HUBUNGAN Pola Komunikasi Orang Tua Asuh dengan Pengetahuan dan Sikap Kesehatan Reproduksi Remaja Panti Asuhan Kabupaten Klaten Tahun 2020. Jurnal Kesehatan Reproduksi, 12(1), $15-25$.

de Onis, M., \& Branca, F. (2016). Maternal and Child Nutrition. Vol. 12. Blackwell 
JURNAL ILMU KESEHATAN BHAKTI HUSADA:

HEALTH SCIENCES JOURNAL

VOL. 12 NO. 02, DESEMBER 2021

DOI: $\underline{10.34305 / J I K B H . V 12 I 2.336}$

Publishing Ltd.

Destiadi, A., Nindya, T. S., \& Sumarmi, S. (2015). Frekuensi Kunjungan Posyandu dan Riwayat Kenaikan Berat Badan sebagai Faktor Risiko Kejadian Stunting pada Anak Usia 3-5 Tahun. Media Gizi Indonesia, 10(1), 71-75.

Hasan, A., \& Kadarusman, H. (2019). Akses ke Sarana Sanitasi Dasar sebagai Faktor Risiko Kejadian Stunting pada Balita Usia 6-59 Bulan. Jurnal Kesehatan, 10(3), 413-421.

Kementerian Kesehatan Republik Indonesia. (2018). Situasi Balita Pendek (Stunting) di Indonesia. Pusat Data dan Informasi Kementrian Kesehatan RI.

Magalena, E. (2014). Pola Pengasuhan Anak Yatim Terlantar Dan Kurang Mampu Di Panti Asuhan Bunda Pengharapan (PABP) Di Kecamatan Sungai Raya Kabupaten Kubu Raya. Tanjungpura University.

Millward, D. J. (2017). Nutrition, Infection and Stunting: the Roles of Deficiencies of Individual Nutrients and Foods, and of Inflammation, as Determinants of Reduced Linear Growth of Children. Nutrition Research Reviews, 30(1), 5072.

Muliyati, H., Purba, T. H., Hasnidar, H., \& Rahmi, N. (2021). Studi Case Control: Kebiasaan Makan dan Hubungannya dengan Kejadian Stunting pada Anak Balita di Desa Padende Kecamatan Marawola. Jurnal Ilmu Kesehatan Bhakti Husada: Health Sciences Journal, 12(1), 1-12.

Mutiara, H., Apriliana, E., Suwandi, J. F., \& OPEn 0 Access
Ciptaan disebarluaskan di bawah

Lisensi Creative Commons Atribusi-

NonKomersial-BerbagiSerupa 4.0

Internasional.

Utami, N. (2019). Screening Pertumbuhan Anak, Edukasi tentang Stunting serta Pelatihan Pemantauan Pertumbuhan Anak pada Orang Tua Siswa Sekolah Dasar Negeri di Provinsi Lampung dalam Upaya Meningkatkan Derajat Kesehatan Anak Indonesia. JPM (Jurnal Pengabdian Masyakat) Ruwa Jurai, 4(1), 36-41.

Nugroho, M. R., Sasongko, R. N., \& Kristiawan, M. (2021). Faktor-faktor yang Mempengaruhi Kejadian Stunting pada Anak Usia Dini di Indonesia. Jurnal Obsesi: Jurnal Pendidikan Anak Usia Dini, 5(2), 2269-2276.

Pusat Penelitian Kependudukan, LPPM UNS, \& Unicef. (2009). Pola Pengasuhan Anak di Panti Asuhan dan Pondok Pesantren Kota Solo dan Kabupaten Klaten.

Rahmad, A. H. A. L., \& Miko, A. (2016). Kajian Stunting pada Anak Balita Berdasarkan Pola Asuh dan Pendapatan Keluarga di Kota Banda Aceh. Kesmas Indonesia, 8(2), 63-79.

Sahanggamu, P. D., Purnomosari, L., \& Dillon, D. (2017). Information exposure and growth monitoring favour child nutrition in rural Indonesia. Asia Pacific Journal of Clinical Nutrition, 26(2), 313-316.

Sari, M. R. N., \& Ratnawati, L. Y. (2018). Hubungan Pengetahuan Ibu tentang Pola Pemberian Makan dengan Status Gizi Balita di Wilayah Kerja Puskesmas Gapura Kabupaten Sumenep. Amerta Nutrition, 2(2), 182 188.

Sumarjono, S. (n.d.). Optimalisasi 
JURNAL ILMU KESEHATAN BHAKTI HUSADA:

HEALTH SCIENCES JOURNAL

VOL. 12 NO. 02, DESEMBER 2021

DOI: $\underline{10.34305 / J I K B H . V 12 I 2.336}$
Ciptaan disebarluaskan di bawah Lisensi Creative Commons Atribusi-

NonKomersial-BerbagiSerupa 4.0

Internasional.

Pemantauan Pertumbuhan sebagai Salah Satu Upaya Pencegahan Stunting pada Anak Balita. Berita Kedokteran Masyarakat, 35(4), 1-7.

World Health Organization. (2014). Challenges and Opportunities. World Health Organization.

Yadika, A. D. N., Berawi, K. N., \& Nasution, S. H. (2019). Pengaruh Stunting terhadap Perkembangan Kognitif dan Prestasi Belajar. Jurnal Majority, 8(2), 273-282. 